\title{
LEGAL REGULATIONS AND THE NATIONAL IDENTITY OF MEMBERS OF THE BELARUSIAN MINORITY IN POLAND
}

\section{Małgorzata Budyta-Budzyńska*}

\begin{abstract}
In the article I address Polish-Belarusian relations in the Białystok region in the second decade of the 21st century - twelve years since the adoption of an Act on national and ethnic minorities and regional language. I discuss changes brought about by the new legislation, how they are assessed by leaders of the minority group, and the possible impact of the bill on the sense of national identity among Belarusians in Poland. In the second part of the article, I describe the main conflict between the Polish majority and the Belarusian minority, which concerns the memory and commemoration of the socalled damned soldiers, and of one of them in particular: Romuald Rajs, alias "Bury".
\end{abstract}

Keywords: Act on national minorities, Belarusian minority in Poland, memorials, Romuald Rajs "Bury"

Creating the English-language version of the journal "Zoon Politikon" is financed under contract No. 724/P-DUN/2018 from the funds allocated by the Minister of Science and Higher Education for dissemination of science.

\footnotetext{
*Małgorzata Budyta-Budzyńska, Ph.D., Collegium Civitas, Warsaw, Poland, e-mail: mbudy@wp.pl ORCID: https://orcid.org/0000-0001-7548-9048
} 
Introduction

In J anuary of 2005, following ten years of systematic labor, the Polish legislature (Sejm) finally passed and Act on national and ethnic minorities and regional language (in the following referred to as Act on minorities). Five years earlier Poland had ratified the Council of Europe's Framework Convention on the protection of national and ethnic minorities, and in 2009 had adopted the Charter for Regional or Minority Languages. Since the ratification of those documents, Poland has been reporting to the Secretary General of the Council of Europe on the implementation of the regulations prescribed therein. This leads to the question: what actual changes in the relations between the minority and the Polish majority have resulted from the adoption of those documents? What issues have been resolved in the twelve years since the adoption of the Act on minorities? What sort of actions and activities have national minorities been compelled to undertake by those regulations, and how may this influence the situation of the minority and its survival as such?

In the present article I discuss these questions with respect to one specific national minority present in Poland: the Belarusian minority. The Belarusian minority inhabits the Northeastern part of Poland Podlasie, mainly around the towns of Białystok and Bielsk Podlaski. It is difficult to give a precise number for the population of this national group, as the level of national awareness varies greatly among its integrants. A frequently given estimate is between 200 and 250 thousand, based on religion and spread of dialect (Budyta-Budzyńska 2010, pp. 182-183, Łodziński 2006, p. 189), however the most recent census (2011) gave a figure of 47 thousand (Gudaszewski 2015, p. 74).

This study was based on ten semi-structured interviews carried out with leaders of the minority in the fall of 2014 and the summer of 2017 in the Podlasie region. The said leaders represented various sectors of 
the community and were engaged in diverse activities: from academic research, teaching, journalism and publishing, to leading artistic groups and events, exhibitions and museums. In the interviews I inquired about the minority's activities, their view of the minority's situation post-2005, the prospects for perdurance of national identity among members of the minority, and existing conflicts between the Belarusian minority and the Polish majority.

The Act on minorities in the view of leaders of the Belarusian minority

The Act on minorities gathered all the extant regulations concerning minorities in a single document and granted the minorities certain new rights. In addition, it prohibited actions by the state which could have a damaging impact on the situation of minorities - such as redrawing limits of electoral districts in a way that alters ethnic proportions in disfavor of the minority group. Furtherly, it compels the state to take actions towards the protection and preservation if minority identities, such as providing subsidies from the central and local government budgets for minority associations, both project-based (which was the case also before the adoption of The Act on minorities) and addressed to the ongoing operation of minority institutions (a long-standing request of the minorities).

The Act restated the right of minorities to usage of their names according to the grammar and spelling rules of their native language, to use the minority language officially as an auxiliary language, and to the naming of towns and physiographic features in the minority language, in addition to the official Polish naming. The latter two regulations apply to those communities (gmina) where a minority comprises at least twenty percent of the population, and the cost of the corresponding road signs is to be covered out of the state budget. 
Furthermore, the Act reaffirmed the right of minorities to radio and TV programs in the public media (Act on national and ethnic minorities and regional language, J anuary 6, 2005). Such programs were present in regional radio and TV channels since the 1990s. In that period, the time allotted to content in minority languages varied; usually such changes, consisting in the reduction of time slots dedicated to minority language programming, triggered protests from the minorities, leading in most cases to restoration of the previous time allotment (BudytaBudzyńska 2003). Additionally, Belarusians in Poland are audience for the programming of the Racja radio and Bielsat television stations, which broadcast from Poland but are mainly addressed to residents of Belarus.

As the leaders stated, the minority makes only partial use of the opportunities created by the Act. Belarusians seldom write their names according to the rules of their native language, due to the strong similarity of the Belarusian and Polish versions. There is no community where the Belarusian language would be officially used as auxiliary language - in official forms and documents, even though the communities: Orla, Czyże, Narewka are inhabited nearly exclusively by Belarusians, and together with the rural commune Hajnówka and Hajnówka the town are registered as municipalities where Belarusian is an auxiliary official language (Urzędowy rejestr gmin 2018). Names of localities and physiographic features in the local language are in official use only in the Orla municipality, although "practically the entire county would be entitled to double naming", as stated by a Belarusian activist from Hajnówka. The local population, however, fears ethnic tensions that could be triggered by bilingual road signs: "There's a recurring fear here. Dual naming could lead to things happening", says one of theleaders. The memory of ethnic conflict that took place in the Białystok region in the 1940s remains vivid, and I will return to this further on. 
The Act and new legislation on the funding of associations, forced minority leaders to start writing grant proposals. What remains a problem is the scarcity of funds, and the fact that only associations and foundations may be beneficiaries of ministry grants, while institutions such as a Belarusian cultural centre cannot. Such regulations compel the minorities to establish more associations in order to be eligible to apply for funding. The optimal solution is to develop activities in affiliation with a Polish cultural centre, funded by the local government, while in parallel registering a minority cultural association. This is how the Belarusian minority in Białowieża operates.

A problem for the Belarusians is the funding of the Belarusian Cultural Centre in Hajnówka. It is supported by its own business activities: rental of premises, hotel and restaurant services, and by foreign aid. The leaders are requesting a systemic solution to the support of minority cultural institutions. The construction of the Cultural Centre in Hajnówka was partially supported by the government of Belarus, however it does not contribute to the costs of operation. The leaders want the central or local government to assume part of the support.

The Act reaffirmed the minority's right, already provided by the Law on Education and a ministerial order, to subsidies for minority schools increased relative to the regular amounts ${ }^{1}$, however, according to Belarusian leaders, in the case of small groups of five pupils the funding is still insufficient to cover the costs. The ministry provides funding for the publishing of textbooks in minority languages, and these textbooks are used by school students for free on loan - the minority is quite content with such a solution. In the recent years, textbooks for initial primary education and for teaching the Belarusian language on all levels

\footnotetext{
' As provided by the Law of Sept. 7, 1991 on the system of education, Art. 13; and the Order of the Minister of Education of Nov. 14, 2007 on the conditions and mode of performance by kindergardens, schools and public institutions of tasks related to supporting the national, ethnic and linguistic identity of students belonging to national and ethnic minorities and communities that use regional languages.
} 
have been published. "We never had it so well before. When we want a textbook, wemake a textbook. The ministry funds it, as long as someone is ready to make it", says one of the activists for Belarusian education.

There are no actual Belarusian schools in Poland, those that are referred to as Belarusian - such as the high schools in Hajnówka, Bielsk Podlaski and Białystok, and several elementary and middle schools, are Belarusian in name only, as all subjects are taught there in Polish, while the Belarusian language is a compulsory but supplementary subject (Strategia rozwoju oświaty mniejszości białoruskiej w Polsce 2014). In Białystok there is also a non-public school operated by the Cyril and Methodius Society, and also there the Belarusian language is taught as an additional language.

In the leaders' opinion, the support given to Belarusian schooling is not sufficient, their expectation is that the state should create a funding model for minority schools and university departments that train minority educators that would allow those establishments to subsist irrespective of economic concerns ${ }^{2}$.

In general, however, most of the minority leaders interviewed were satisfied with the opportunities created by the Act; "I wish we were only able to take full advantage", said one of the activists. They pointed out that the Act brought some order into the subject, by collecting all regulations pertinent to minority rights in a single Act that provides a point of reference to politicians, officials and activists and creates a legal space for action. Funding for minority association has been guaranteed, and even if insufficient, it is subject to clear and transparent rules within which the leaders have learned to operate ${ }^{3}$.

\footnotetext{
${ }^{2}$ The Chair of Belarusian Studies at the University of Białystok was abolished in 2014. It was created in the 1990s on the initiative of Jerzy Giedroyc, however once he had deceased there were repeated attempts to abolish it, which finally succeeded. This was argued on the grounds that there were too few students enrolling. In the opinion of the Belarusians, the importance of research conducted at the Chair and the duty of the authorities to maintain correct relations with the minority group were sufficient grounds to keep the Chair. 3 Will Kymlicka and Charles Taylor wrote that the state ought to establish special rights for national minorities as a matter of leveling opportunities, and in this consists the concept of ethnocultural justice
} 
The Belarusian minority, twelve years after the Act on minorities

Potentially the Belarusian enjoy the best conditions for minority activism among all national minorities present in Poland: they are relatively numerous, reside in concentration in their historical homeland, and free of guilt rising from World War 2 events. According to the 2011 census, 44.1 thousand Polish citizens defined themselves as Belarusian by nationality (Gudaszewski 2015, p. 100) ${ }^{4}$; comparing with the figure from the 2002 census - where 47.64 thousand Polish citizens declared themselves to be of Belarusian nationality (Gudaszewski 2006, p. 100), the Belarusian minority has shrunk in number ${ }^{5}$. Clearly a serious issue for the Belarusian is the fragility of their national identity.

When questioned on this subject in 2014, Belarusian leaders expressed a variety of opinions. Some stated that the Belarusian identity is weak and feeble, and the number of persons who identify as Belarusian is dwindling dramatically: "all that's left are remains, some sort of relics, who won't even openly admit their identity", said one cultural activist from Krynki. "Those who undertake any activities do it for therapy, for themselves and the community, so it won't be afraid, to lend itvalue,

(Kymlicka 1995, Taylor 1992). Leaders of national minorities in Poland have requested diverse rights for different minorities, as each one of them has different concerns; matters which are a priority for one, e.g. bilingual names which are of importance to Germans, do not matter that much to Lithuanians and Belarusians, for whom education is the top issue.

4 Belarusian leaders complained that the census was not carried out properly; sometimes census takers failed to ask the right questions, in addition some people felt intimidated and for this reason withheld declaration of Belarusian nationality.

5 Unlike in the 2002 census, in the 2011 census it was possible to state more than one nationality, pointing out the primary one if the person so chose. As a result, the total number of people belonging to national and ethnic minorities, as indicated by either primary or secondary nationality declares as non-Polish, grew considerably - with the exception of Belarusians and Germans. Those belonging to the Belarusian minority declared non-Polish nationality as primary in $77.8 \%$ of cases, more frequently than did other minorities, while they less frequently declared more than one nationality. The number of those declaring Belarusian nationality dropped in rural areas (by 6 percent), while it grew among urban dwellers (by $2 \%$ ). However, this should not be taken to mean that the rate of assimilation in the cities dropped; rather, it is due to ongoing migration from the countryside to the cities (Gudaszewski 2015, pp. 89-90). The 2011 census also showed that Belarusians are the minority with an age structure most biased towards old age: their median age was 51.6 years, that is 13.5 years more than the median for the Polish population in general. 
to reduce its complexes. If things continue the way they are, then in the near future nothing will be left except graveyards and memorials. The Belarusian minority will be referred to just like we presently talk about the J ews, when there are no J ews; it will become possible to speak openly, as nobody will be threatened anymore".

Others, however, point to changes taking place within the Belarusian community, and say that Belarusian identity has evolved compared to even only ten or more years ago, "became far more interesting, multifaceted and complex", in the words of one leader from Białystok. Recent years have seen the rise in activity of a relatively numerous group of Belarusian intelligentsia with increased awareness of their own identity and a strong attachment to their small homeland. "Here is where I inhabit and live, I wouldn't be able to exist anywhere else. I feel at home here, this is the land that powers me", says one Belarusian leader. Another leader gave a very similar explanation for his decision to remain in Hajnówka: "This is my place on Earth, I made a conscious decision to stay here. I feel well in my small homeland". The local Belarusians identify strongly with their home region, as a cultural and geographic entity, while their bonds with the Belarusian state are either weak or non-existent.

Currently the Belarusian community consists mainly of 40-50 yearold who were part of the Belarusian Students' Union in the 1980s and later. They differ from the previous generation of activists of the Belarusian Social and Cultural Association, who were burdened by complexes, entitled, passive, and reliant on state assistance (BudytaBudzyńska 2003, pp. 165-172). They engage in numerous activities, not just folklore-related, but innovative, addressing adults as well as youth and children. In recent years one may observe a surge in activity in Belarusian education, especially in Białystok, where an Association for children and youth learners of the Belarusian language named AB-BA 
has developed vigorously, and in Białowieża, where no Belarusian language classes were available until recently. It appears that assimilation has slowed down in the Białystok region, although according to the leaders, part of the Belarusian community remains fearful of speaking their language or joining a Belarusian association. They limit themselves to listening to Radio Racja and other Belarusian radio programming, and speaking the local dialect at most at home, while switching to Polish whenever they are in public.

Still, the leaders have faith in the young people, raised in the post1989 period. 'Young people are at ease speaking Belarusian, attending Belarusian dance parties, announcements and posters in Belarusian are put up in Białystok and nowadays, nobody is startled by this, while in the past this was unthinkable" - spoke one of the interviewees, "because today it's no longer just the countryside and its local dialect, it's an urban community, educated and free of complexes, aware of its identity". A factor of prime significance is the level of instruction in Belarusian schools. In the 1980s the so-called Belarusian schools, e.g. those that offered Belarusian as a second language, had an image of schools for rural children, while at present the Belarusian high school in Hajnówka is renowned for its high level of instruction, also enrollment in the non-public Cyril and Methodius Foundation School is in great demand. One of the activists admitted that this is at least in part a result of the Act on minorities.

Each one of the interviewed leaders arrived at his or her Belarusian identity along a different path. One had an interest in music, played several instruments and engaged in various musical initiatives, from punk to rock and metal, but once he found himself in a folk band he discovered that this was what he was looking for. So began his adventure, initially with Belarusian music, later on with the language, which was spoken at home but was not taught or cherished, and finally with Belarusian culture. 
One of the leaders (female) discovered her Belarusian identity while in London as an immigrant. Before leaving for Great Britain she identified as Polish, only once she emigrated she felt compelled to question her identity. "The parish members at the Russian Orthodox church in London became my foster family - among them were Ukrainians, Belarusians and Orthodox Poles. I discovered that the hymns sung in Polish church were not mine. I felt a stranger and stigmatized among the fundamentalist Catholic emigrants. I feared to admit that I speak Belarusian. I began to sing with the London Russian Choir and thus became part of the Eastern Orthodox community in London, and found I felt more comfortable and at home there than among the Poles in London".

Several of the leaders gave a similar story: their parents spoke Belarusian dialect between themselves and with the grandparents but addressed their children in Polish and required them to speak Polish. To them Polish was the language of social advancement and symbol of a better life. "I believe they did not want me to know Belarusian", said one of the activists engaged in teaching the Belarusian language.

Their Belarusian identity was discovered in adulthood. "Belarusian was my personal decision", said one of the interviewees. "T realised that in spite of the presence at home of the Polish language, this was not Polish culture: when the family gathered, they sung only Belarusian songs, in the Belarusian language. If then I am not Polish, as culturally I cannot be, who am I? Not merely a local, that may have been a suitable definition in the 19th or early 20th century. Certainly, I am more familiar with Polish language and literature, still the Belarusian language matters greatly to me. At a certain moment I stopped talking with my parents in Polish, although my sister remains a Polish speaker exclusively". The children returned to the language of their grandparents, despite their parents' efforts to separate them from it. 
The conflict around memory

In the Białystok region, ethnic tensions arise mainly from events of the past. Following a relative calm in the first decade of the 21st century, currently disputes are triggered by the numerous commemorations of the "damned soldiers", of whom the collective memory of the Belarusians differs greatly from the official historical narrative promoted by the state $^{6}$. The conflict is centred around the person of Romuald Rajs alias "Bury", whose troops assaulted several Belarusian villages in J anuary and February of 1946.

The background behind the burning down of the villages and the murder of 79 villagers is not quite clear, it is known, however, that the operation carried out by "Bury's" detachment was not accidental. In J anuary of 1946, the Third Wilno Brigade of the NZW (National Military Union) was concentrating its troops in the Białowieża forest. At the same time, the (Communist) administration of the Orla municipality ordered the local haulers to transport wood from the forest?. "Bury" saw this as an operation against his detachment, and in late January his guerrilla troops captured in the forest close to the village of Łozice (nearby Hajnówka) forty haulers (horse cart drivers) who were carrying wood out of the forest. Their carts were requisitioned, and while those who declared themselves to be Polish were released, the remaining 29 were shot in the neighborhood of the village Puchały Stare. In the following days, the detachment went on a rampage through the surrounding Belarusian villages, burning down the following villages: Zaleszany, Wólka Wygonowska, Zanie, Szpaki, Końcowizna, Popówka, Rajska,

\footnotetext{
${ }^{6}$ It should be stressed that tensions related to the "damned soldiers" did not first arise after the 2015 elections but were present before that. As pointed out by the interviewees, a climate of fear started to arise since 2011, which was when the memory of "damned soldiers" began to be restored.

7 The Polish and Belarusian sides give different cause and effect descriptions of events from the late 1940s. According to Belarusians, actions by the Polish underground compelled Belarusians to associate with the Communist state apparatus; while according to some local Poles, it was the participation of Belarusians in the Communist regime that triggered actions by the anti-Communist underground in the Białystok region.
} 
Sypnie, Potoka; killing fifty persons in total, and 79 counting the haulers $^{8}$ (Chmielewska, Drozdowska, Gogolewska 2010, p. 19) ${ }^{9}$. This operation was condemned by part of the NZW, and "Bury" was to be courtmartialed by the organization, though ultimately this never happened. After the fighting was over, in 1948 Rajs was arrested and sentenced to death in a show trial, which took place in Białystok's Ton cinema house. He was executed on New Year's Eve of 1949, and the place of his burial remains unknown.

In 1995, a Warsaw military court declared him innocent, ruling that all the acts he committed were in connection with actions for the independence of the Polish state. His orders of the pacification of those villages were issued under circumstances of force majeure (Moroz 2016). In the opinion of Belarusians, the court had rehabilitated a murderer, and the demand was raised for a further investigation into the deaths of the haulers. In March of 1997 an inquiry was launched, with the conclusion that there was no evidence that the victims were involved in the structures of the Communist state, and the murder was tentatively classified as a crime against mankind (which is not subject to a statute of limitation). In 2005 the investigation was closed on the grounds that those involved in the crime had deceased,

In the mid-1990s, a Committee of Families of Victims of Murders Committed in J anuary and February of 1946 by the Polish Underground was established. The Committee requested from the local Commission for Investigation of Crimes against the Polish Nation in Białystok that the remains of the haulers, buried at the Roman Catholic cemetery in Klichy, be exhumed and transferred into a common grave at the (now

\footnotetext{
${ }^{8}$ According to one version, echoed by one of the Belarusian leaders, the burning down of the village may have been in retaliation for shots fired on the detachment as it was marching through a Belarusian village. 9 In 1939, when the "Prussia" Army of which Rajs's detachment was a part was dispersed, a group of soldiers he was in charge of was detained by an armed Belarusian group and taken to the fort of Bereza Kartuska to be disarmed. According to some, that event had some impact on Rajs's attitude towards Belarusians (Jan Kułak: article on Rajs, in: The underground and social resistance in Poland 1944-1956, a biographical collection, cited by Moroz 2016).
} 
closed for burials) military cemetery in Bielsk Podlaski. A memorial was erected, paid for by the government, however the inscription remained a matter of dispute. The Committee requested that the memorial should be dedicated to all those who were killed by "Bury's" guerrillas in 1946, rather than just the haulers. The government Council for Memorials of War and Martyrdom, together with the head of the voivodeship administration, disagreed and voiced that the inscription should commemorate no more than those who were actually buried at the cemetery ${ }^{10}$.

The issue became stuck in litigation and was heard several times before the Head Administrative Court, but in the end the memorial Committee agreed to change the proposed inscription, and the memorial was inaugurated in October of 2002. Instead of "Glory to their memory", the sign on the memorial reads: "Dear God, may they be given what they were deprived of, and may the living never suffer such a fate". On the side plaques, instead of the proposed text "In homage to those murdered by the armed underground", the inscription reads "In homage to those murdered by the Special Operations Detachment of the NZW under the command of Captain Romuald Rajs alias "Bury".

A second conflict arose around a memorial to the Eastern Orthodox inhabitants of the Białystok region who were murdered, killed or missing in the years 1939-1956. In 1997 a Memorial Association was established and began to collect funds for a statue to be erected in the centre of Białystok, in front of the Saint Nicholas Orthodox Church. The head of the voivodeship objected, and in the end the memorial was erected after fifteen years on the grounds adjacent to the Holy Spirit Orthodox Church in Białystok ${ }^{11}$. A plaque in the base of the monument bears inscribed the names of the villages destroyed by "Bury's" guerrilla and the

\footnotetext{
${ }^{10}$ Even the burial itself at a military cemetery was an issue. The victims were not military personnel, thus their burial there required special administrative procedures.

"I have written before on conflicts in the Białystok region: Budyta-Budzyńska 2003. Some of those conflicts had their source in ideological differences and political leanings among the Poles and Belarusians who inhabit the region. Diverging political inclinations often lead to prompt and easy social labeling, and
} 
inscription: "To the Orthodox victims of World War II, martyred for the faith and the nation in the years 1939-1945, saints of the land of Podlasie"12. $^{\prime \prime}$.

The setting up of these monuments did not end the disputes, from 2011 onwards the conflict of memory in the Białystok region transitioned into a second phase. This one has to do not with the Belarusian monuments, but with the commemoration of the "damned soldiers", of whom Romuald Rajs alias "Bury" is considered to be one. A large number of articles were published in the local press about the guerrilla activities in the region, lauding the detachment and its commander, monuments and memorial plaques were dedicated to the underground fighters in the villages of Augustowo and Śliwowo, in Białystok, Bielsk and Narewka ${ }^{13}$. New memorial events were introduced, such as the annual Podlasie Rally along the path of the 5th Wilno Brigade of the Home Army (a part of which are ceremonies dedicated to commemorating the execution of Danuta Siedzikówna alias "Inka”, a nurse from the Łupaszka detachment), and the March in Commemoration of the Damned Soldiers in Hajnówka.

As argued by scholars who studied issues of memory, the mode of commemoration is of great importance, because it is what determines how events are remembered, and even (to a degree) what is remembered. Collective memory appears to be determined by the past, but ac-

the labels so created tend to be robust and resistant to change, sometimes even in the face of great social and political transformations.

${ }^{12}$ MP Eugeniusz Czykwin set up a cross with a plaque inscribed with the names of the victims at the site of a house burned down by the "Bury" detachment. The nearby monastery of St. Catherine houses an icon of the Holy Mother of Zaleszany, made in 2013, whose author alludes to the events of 1946; on the lower part of the picture we see a house on fire on one side, and children in flames on the other.

${ }^{13} \mathrm{~A}$ monument in the village of Augustowo, near Bielsk Podlaski, is dedicated to Polish Underground soldiers fallen on the Eastern frontiers of the Second Republic in combat against the Soviets in the years 1994-1954; a plaque on the Ton cinema in Białystok commemorated the show trial at which Rajs was sentenced; a Damned Soldiers Roundabout was established in Białystok in 2014, against objections from the Eastern Orthodox; a monument to "Inka” Siedzikówna in Narewka. 
tually it is at least in part transformed by present acts of commemoration and the sense that the past is endowed with retrospectively (Lavabre 1995). This makes disputes about commemoration to be not just about rituals, but about the essence of collective memory.

The mentioned monuments, rally and especially the march that is held regularly since 2016 have been triggering protests among the Eastern Orthodox inhabitants of Podlasie (and more than just them, the marches in 2017 and 2018 were protested by the Citizens of the RP movement). "There is a fear that grows from the past, from the history of the Wilno brigade commanded by Col. Romuald Rajs alias "Bury", and the murder of the Belarusian haulers", said one of the interviewed Belarusian leaders, and similar opinions were voiced by the remaining. One of the activists recalled that when she led an ethnographic workshop with children from the villages Zanie and Szpaki, which were burned down by "Bury's" detachment, the children were baffled that nobody in the village was willing to tell them about family history.

In March of 2014 in the Cultural Center at Hajnówka a meeting was held, called by the Cyril and Methodius Orthodox Brotherhood, on the subject "Romuald Rajs alias »Bury«: not our hero". Two motion pictures were shown, made by J erzy Kalina - a filmmaker of Belarusian descent from the local Białystok TV channel, about the pacification of Belarusian villages by "Bury's" detachment, and the later disputes around the burial of his victims. This meeting was widely commented upon, and the management of the Cultural Center was accused of supporting Belarusian radicals. As a response to this event, an initiative under the name "National Hajnówka" was established, and since 2016, in connection with the ONR (national movement) and football fans of the team J agiellonia Białystok, it has been hosting meetings with journalists from right newspaper "Nasz Dziennik" and right television TV Trwam, and the controversial and emotion-evoking March in Memory of the Damned Soldiers. 
While describing the conflict around "Bury", Anna Moroz speaks of a clash of two discourses: the independentist-patriotic, which focuses on the underground's actions against Soviet occupation, where "Bury" takes the role of a hero, and the actions of his detachment are viewed as punishment dealt to the haulers for collaborating with the Communists; and the Belarusian, which focuses on "Bury's" victims, while he is viewed as a criminal, and the acts carried out by the guerrillas (the forest people, as the Belarusia discourse refers to them) are described as ethnically and religiously motivated murder. The difference between the two discourses is not about the facts, but about the interpretation of "Bury's" actions and stance. The patriotic discourse stresses ideological differences between Poles and Belarusians; while the Belarusian discourse points to ethnic and religious differences, which led to ethnic prejudice and were the actual motives behind the murders.

The conflict around "Bury" is, however, not just about discourse, it is also about memory and the mode of commemoration. Moroz (2016) writes on the stigmatization of the collective memory of Belarusians, as an "Eastern" one, meaning inferior, less important, that need not be reckoned with. In my opinion, a more useful category is that of frontier, which may be understood not just as a territory inhabited by a diversity of ethnic groups, but also as a peripheral one, where the rules and norms observed in more central parts do not apply. Frontier signifies both the ethnic indefiniteness of a territory, and a normative fluidity or arbitrariness. Such territories are not fully defined, and it follows that more is allowed there, actions are admissible which would be unacceptable in the proper territory (Budyta-Budzyńska 2010, p. 258).

Moroz quotes from Barbara Szacka's essay How we tell the past: "There are two accounts of the war. One speaks of the major events of history. The other talks about what people went through. In the former, the nation is the subject, while in the latter it's the individual. Each of 
those accounts is constructed around a different set of topics and employs a different language. In the former, there are heroic deeds; in the latter - fear and pain" (quoted from Moroz 2016, p. 53).

In the case of the Belarusian haulers we are dealing with both types of memory, further set apart by the fact that the former refers to acts by Poles, while the latter - to the pain of Belarusian families. There is yet one further mechanism in operation: the history of the haulers' families is no longer just individual biographical memory, it has become cultural memory for the Belarusian minority in Poland.

Once direct witnesses of events die, putting an end to communicated history, but history continues to be remembered and transmitted to the next generations, individually communicated memory becomes replaced by collective cultural memory (Assmann 2009). The intergenerational transmission is of great importance, since it becomes one of the preconditions of the community's perdurance in a social and cultural sense, and an element that gives it roots in the hic et nunc.

This is precisely what happens with the memory of the haulers. To Belarusians in Poland, memory of events connected with the acts of "Bury's" detachment has become cultural memory, or even foundational. In the 1940s, inhabitants of the Białystok region were referred to as "locals" or Eastern Orthodox; "at those time I would not be shouted at as a Belarusian, but as a local", said a teacher from Hajnówka. Today the haulers murdered by "Bury's" detachment are referred to as Belarusians, and the memory of the events of the latter 1940s has become one of the correlates of national identity, an element of foundational memory. Might the monument on the grave of the exhumed haulers become with time a place of memory for Belarusians in Poland? 
The Act on minorities set up guarantees for the language, cultural and educational rights of minorities and defined a path for funding the activities of minority associations, thus creating a suitable space for action, and the Belarusian leaders were able to position themselves within this space. In general, notwithstanding earlier reservations, Belarusian leaders view the Act rather favorably. Current tensions in the Bialystok region are focused nearly exclusively on the collective memory of events of seventy years ago and the commemoration of those events. An intense flagging of nationality by one group always triggers a reaction, which is a similar flagging by the other group (Billig 2008). Historical figures regarded as heroes by one group are not at all heroes to the other. The main conflict between the Polish majority and the Belarusian minority concerns the activities of "damned soldiers", for example "Bury", who operated in the region in the final period of WW2 and directly thereafter.

Commemorations of those events bring back the recollection of the victims on the other side of the conflict: the murdered Belarusian peasants, and thus spin a spiral of mutual accusations and suspicion. The true problem is that while one community demands that the truth be told, what is meant is not just the magnification of their own suffering, but also a belittling of the suffering of others, said British historian Tony Judt in a conversation with the American historian Timothy Snyder years ago (J udt, Snyder 2012, pp. 62-63).

This is precisely the case on the Polish-Belarusian frontier. This is further augmented by memories of the more recent past. One recurring thread in interviews with Belarusian leaders was that of rumors circulating during martial law (1981-82) and still often repeated, of Poles marking the homes inhabited by the Eastern Orthodox in order to settle accounts with them at a later date. It does not matter that this was merely a rumor - what matters is that many believed it, and still believe 
it thirty years later. This sort of narrative creates a climate of intimidation and "moral panic" - to employ a currently popular term. "You know, I'm not even sure whether people just wound themselves up by inventing such fears or were they truly afraid. I recall the stories that came with the proclamation of martial law, that homes inhabited by the Orthodox in Bielsk had been marked with crosses, I believe such stories were spread on purpose. For the purpose of sowing a climate of panic and intimidation", said one of the Belarusian leaders.

\section{References}

Act on national and ethnic minorities and regional language [Ustawa z 6 stycznia 2005 roku o mniejszościach narodowych i etnicznych oraz o języku regionalnym] (2005), Dz.U. 2005, nr 17, poz. 141, http://prawo.sejm.gov. pl/isap.nsf/ download.xsp/WDU20050170141/U/D20050141Lj.pdf

Assmann J . (2011), Cultural Memory and Early Civilization: Writing, Remembrance, and Political Imagination, Cambridge University Press, Cambridge- New York

Billig M. (1995), Banal Nationalism, Sage, London-Thousand Oaks

Budyta-Budzyńska M. (2010), Socjologia narodu i konfliktów etnicznych [Sociology of the Nation and Ethnic Conflicts], Wydawnictwo Naukowe PWN, Warszawa

Budyta-Budzyńska M. (2003), Mniejszości narodowe - bogactwo czy problem? Instytucjonalizacja mniejszości narodowych $w$ Polsce $w$ latach 1989-2002 [National Minorities, an Asset or a Problem? The Institutionalization of National Minorities in Poland in 1989-2002], Instytut Studiów Politycznych PAN, Warszawa

Chmielewska A., Drozdowska J., Gogolewska J. (2010), W godzinę próby. Żotnierze podziemia niepodległościowego w Białymstoku po 1944 roku i ich 
losy [In the Hour of Trial. Soldiers of the Pro-independence Underground in Biatystok after 1944 and their Fates], Instytut Pamięci Narodowej, Białystok Connerton P. (1989), How Societies Remember, Cambridge University Press, Cambridge- New York

Gudaszewski G. (2015), Identyfikacje etniczne w Narodowym Spisie Powszechnym Ludności i Mieszkań w 2011 roku [Ethnic self-identification in the National Census of Population and Homes, 2011], (in:) Mniejszości narodowe i etniczne $w$ Polsce $w$ świetle Narodowego Spisu Powszechnego Ludności z 2011 roku [National and Ethnic Minorities in Poland in Light of National Census of Population, 2011], (Eds.) Łodziński S., Warmińska K., Gudaszewski G., Wydawnictwo Naukowe Scholar, Warszawa

Gudaszewski G. (2006), Demograficzno-społeczna charakterystyka obywateli polskich deklarujacych „narodowość niepolska” $w$ Narodowym Spisie Powszechnym $w 2002$ roku (Demographic and social characterization of Polish citizens who declared "non-Polish" nationallity in the National Population Census of 2002), (in:) Mniejszości narodowe $w$ Polsce $w$ świetle Narodowego Spisu Powszechnego Ludności z 2002 roku [National Minorities in Poland in Light of National Census of Population, 2002], (Eds.) Adamczuk L., Łodziński S., Wydawnictwo Naukowe Scholar, Warszawa Halbwachs M. (1992), On Collective Memory, University of Chicago Press, Chicago J anowicz S. (1987), Białoruś, Białoruś [Belarus, Belarus], Iskry, Warszawa JudtT., Snyder T. (2012), Thinking the Twentieth Century, Penguin Press, NewYork Kymlicka W. (1995), Multicultural Citizenship: A Liberal Theory of Minority Rights, Oxford University Press, Oxford

Lavabre M. (1995), Entre mémoire et histoire: á la recherche d'une méthode, (in:) La guerre civile entre histoire et mémoire, (Ed.) Martin J ., Université de Nantes, Nantes

Łodziński S. (2006), Trauma i władza liczb. Wybrane problemy społecznego odbioru pytania o „narodowośc” w Narodowym Spisie Powszechnym z 2002 roku [Trauma and the power of numbers. Selected problems of the social response to the "nationality" question in the National Population 
Census of 2002], (in:) Mniejszości narodowe $w$ Polsce $w$ świetle Narodowego Spisu Powszechnego Ludności z 2002 roku [National Minorities in Poland in Light of National Census of Population, 2002], (Eds.) Adamczuk L., Łodziński S., Wydawnictwo Naukowe Scholar, Warszawa Moroz A. (2016), Między pamięciq a historią. Konflikt pamięci zbiorowych Polaków i Białorusinów na przyktadzie postaci Romualda Rajsa Burego [Between Memory and History. Conflict of Collective Memories between Poles and Belarusians as Exemplified by the Person of Romuald Rajs „Bury”], Instytut Pamięci Narodowej, Warszawa

Urzędowy rejestr gmin [Official registry of municipalities] (2018), Ministerstwo Spraw Wewnętrznych i Administracji, Warszawa, http://mniejs zosci.narodowe.mswia.gov.pl/mne/ rejestry/ urzedowy-rejestr-gmin/ 6884, Urzedowy-Rejestr-Gmin-w-ktorych-jest-uzywany-jezyk-pomocniczy.html Strategia rozwoju oświaty mniejszości białoruskiej w Polsce [Strategy for the development of education for the Belarusian minority in Poland] (2014), Warszawa- Białystok, http:// www.kuratorium1.home.pl/kuratorium2/jez mniej/str_rozw.pdf

Taylor Ch. (1992), The Politics of Recognition, (in:) Multiculturalism and "The Politics of Recognition", (Ed.) Gutman A., Princeton University Press, Princeton 